\author{
Univerzitet u Beogradu \\ Poljoprivredni fakultet \\ Institut za poljoprivrednu tehniku \\ Naučni časopis \\ POLJOPRIVREDNA TEHNIKA \\ Godina XLVI \\ Broj 1, 2021. \\ Strane: $1-6$
}

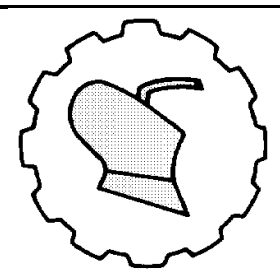

University of Belgrade

Faculty of Agriculture

Institute of Agricultural Engineering

Scientific Journal

AGRICULTURAL ENGINEERING

Year XLVI

No. 1, 2021. pp: $1-6$

\title{
THE IMPORTANCE OF OPERATING AGRICULTURAL EQUIPMENT IN USE BY FAIR VALUE FROM THE MANAGEMENT SITUATION IN SMALL AND MEDIUM-SIZED ENTERPRISES IN THE TRANSITIONAL COUNTRY, -EXAMPLE OF THE REPUBLIC OF SERBIA
}

\author{
Jelena Vitomir ${ }^{1}$, Sonja Tomaš-Miskin ${ }^{2}$, Slobodan Popović $*^{3}$ \\ ${ }^{I}$ Megatrend University, Faculty of Business Studies, Bulevar Maršala \\ Tolbuhina 8, 11070 Novi Beograd, Republic of Serbia \\ ${ }^{2}$ Economic School of Banja Luka, Kralja Alfonsa XII/34, 78000 Banja Luka, \\ Bosnia and Herzegovina \\ ${ }^{3}$ Public Utility Company, "Gradsko zelenilo", Temerinski put bb, \\ 21000 Novi Sad, Republic of Serbia
}

Summary: This study highlights the importance of using real-life values of agricultural equipment in real financial statements in medium-sized enterprises. The authors have adopted the essence of nature related to the estimation of agricultural equipment, that is, he has stated that in the agricultural production of transition countries, agricultural equipment has been used for more than five decades. This was a key assumption adopted by the authors of this study. In addition, the presentation of realistic financial statements should include an account of the real value of agricultural equipment, which essentially leads to a periodic fair valuation of agricultural equipment available to agricultural producers in transition countries.

Key words: agricultural equipment, fair valuation, enterprise. 


\section{INTRODUCTION}

In the literature dealing with fair valuation of agricultural equipment, an analysis of the importance of the use of fair value in the presentation of agricultural equipment in company books is increasingly encountered. Dominantly, fair valuation of agricultural equipment is analyzed in the SMEs of transition countries [1], [2], [3], [4], [5].

Another important feature that accompanies fair value of agricultural equipment and its fair value in the financial statements of an enterprise is the application of a number of standard methods [6], [7], [8], [9], [10] that are introduced in the process self evaluation of agricultural equipment.

Thus, the current principle related to standardization of accounting observation is substantially changing in favor of fair valuation of the said equipment in enterprises.

Over the last 20 years, there has been a growing interest from a number of authors who have pointed to possible improvements in structural management in companies if they improve financial reporting in companies [11], [12], [13], [14], [15].

Only financial reporting in companies is focused on the increasing application [16], [17], [18], [19], [20] of the introduction of fair value of all assets in the books of account, and therefore of agricultural equipment.

\section{MATERIALS AND METHODS}

The study was started with a SWOT analysis because the author wanted to start the research with a presentation of initial knowledge about the use of fair value of agricultural equipment, which in the region that once covered the territory of the former Yugoslavia is mainly in business in small and medium-sized enterprises.

Therefore, this analysis serves to ensure that the results obtained can be compared and applied in further research activities, primarily in the field of agriculture.

The research included obtaining valid information from top management that was done in 20 medium-sized enterprises in the Republic of Serbia. Agricultural equipment by age is analyzed in the intervals 1965-1975, 1975-1985, 1985-1995, 1995-2005, 20052015, 2015-2019. The interval of observed equipment used in use covered the period from 1965 to 2019, that is, at that age the equipment was still in use and shown in the books of account at fair value.

The agricultural equipment of enterprises in terms of measuring their performance in terms of value refers to equipment used on a daily basis. The expression of equipment at fair value should be the standard to which the author points out in the study below.

The research presented in the study relies on an analysis of top management behavior in corporate governance, and the primary objective of the judge's author was to show the importance of determining the actual measured fair value of the agricultural equipment used in the enterprises in use.

\section{RESULTS}

Initial study results are based on the application of SWOT analysis, i.e. 
The author presented: available options, perceived weaknesses, opportunities and threats to the agricultural enterprise. So the first goal is fulfilled.

In other words, the main attributes have been identified that relate to the importance of measuring agricultural equipment used at fair value mainly in small and medium-sized enterprises in the country in transition, and in this case the survey was dominantly conducted and relates to the territory of the Republic of Serbia.

Table 1. SWOT analysis illustrating the fair value situation of agricultural equipment in the books of predominantly medium-sized enterprises in the Republic of Serbia

\begin{tabular}{|c|c|}
\hline Available options & Weaknesses \\
\hline $\begin{array}{l}\text { - application of the IAS adopted at the national } \\
\text { level in the process of EU accession; } \\
\text { - unqualified opinion of external auditors for } \\
\text { enterprises that already measured agricultural } \\
\text { equipment in use at fair value; } \\
\text { - presenting agricultural equipment in use at fair } \\
\text { value encourages application of standardization } \\
\text { by top management in enterprise governance }\end{array}$ & $\begin{array}{l}\text { - lack of information on strengths in fair } \\
\text { valuation of agricultural equipment in use } \\
\text { by enterprises; } \\
\text { - lack of prescribed procedures relating to } \\
\text { top management bonuses for improved } \\
\text { performance of enterprises they are in } \\
\text { charge of; } \\
\text { - inadequate policy of punishment due to } \\
\text { inappropriate managerial decisions and } \\
\text { poor management by top executives of } \\
\text { enterprises }\end{array}$ \\
\hline Opportunities & Threats \\
\hline $\begin{array}{l}\text { - increase in compatibility with positive business } \\
\text { practice of the EU and developed countries; } \\
\text { - greater reliability of financial reporting of top } \\
\text { management, owners and shareholders; } \\
\text { - providing safety of operations of international } \\
\text { companies in the Republic of Serbia; } \\
\text { - increase in general certainty of doing business } \\
\text { and corporate governance; } \\
\text { - fair valuation of agricultural equipment in use by } \\
\text { enterprises facilitates borrowing from business } \\
\text { banks; } \\
\text { - facilitated decision-making on joint investments } \\
\text { with foreign companies }\end{array}$ & $\begin{array}{l}\text { - non-harmonized legal regulations with } \\
\text { those of developed countries; } \\
\text { - slow transformation of state-owned } \\
\text { enterprises into private companies or joint } \\
\text { stock companies; } \\
\text { - increase in tax on assets based on the } \\
\text { increase in the value of agricultural } \\
\text { equipment measured at fair value }\end{array}$ \\
\hline
\end{tabular}


Table 2. Display of fair value of equipment at observation intervals by age of the

\begin{tabular}{|c|c|c|c|}
\hline \multirow{2}{*}{$\begin{array}{c}\text { Observation of } \\
\text { equipment age } \\
\text { interval }\end{array}$} & $\begin{array}{c}\text { Age agricultural } \\
\text { equipment } \\
\text { observed at } \\
\text { intervals within } \\
\text { the year }\end{array}$ & $\begin{array}{c}\text { Valued agricultural equipment at fair value } \\
\text { individually evaluated } \\
\text { equipment }\end{array}$ & $\begin{array}{c}\text { Number } \\
\text { Description of the } \\
\text { significance of the } \\
\text { expression of the equipment }\end{array}$ \\
\hline 1 & $1965-1975$ & 2 & little \\
\hline 2 & $1975-1985$ & 8 & little \\
\hline 3 & $1985-1995$ & 14 & middle \\
\hline 4 & $1995-2005$ & 20 & high character \\
\hline 5 & $2005-2015$ & 30 & high character \\
\hline 6 & $2015-2019$ & 5 & little \\
\hline
\end{tabular}

\section{DISCUSSION}

Based on the results of the study, the study shows that agricultural equipment is used over a large interval of its age (the year in which it was produced). The interval at which the equipment was still in use covered the survey period 1965-2019.

The interval by age criterion of the used equipment used included the observation period 1965-2019, that is, at that age the equipment was still in use and shown in the books of account at fair value.

The large interval of expression of the fair value of agricultural equipment essentially indicates that it is in use even though it is old, but it is used for performing agricultural production work.

The last column required the top management to outline their observations regarding the equipment used and, depending on its importance, to indicate three degrees of graduation of importance to the company (small, medium and significant levels of enterprise management).

\section{CONCLUSIONS}

Through this research, the author of the study presented several important characteristics of agricultural equipment, which is still practically used in the ordinary course of business, and which is kept in the books of account "Fair-values".

First there is a small number of agricultural equipment that is extremely old but still used in the production process in an agricultural enterprise.

Dominantly the largest number of individually reported equipment kept in the books of the company is of age in the interval 1995-2015, which indicates which equipment is the most represented in real exploitation in the enterprises. 
This attitude was also strengthened by people who rated the importance of these equipment with descriptive ratings, that is, the top management of the enterprises run by the aforementioned medium-sized agricultural enterprises.

\section{REFERENCES}

[1] Arena, M., Arnaboldi, M. and Azzone, G. 2006. Internal audit in Italian Organizations: a Multiple Case Study. Managerial Auditing Journal, 21(3): pp. 275-292.

[2] Barlev, B. and Haddad, J. (2003). Fair value accounting and the management of the firm. Critical Perspectives on Accounting, 14: pp. 383-415.

[3] Bozzolan, S., Laghi, E., and Mattei, M. 2016. Amendments to the IAS 41 and IAS 16 implications for accounting of bearer plants. Agric. Econ. - Czech, 62: pp. 160-166.

[4] Bratten, B., Jennings, R. and Schwab, C. 2016. The accuracy of disclosures for complex estimates: Evidence from reported stock option fair values. Accounting, Organizations and Society, 52: pp. 32-49.

[5] Cai, F. and Wong, H. 2010. The effect of IFRS adoption on global market integration. International Business \& Economics Research Journal, 9(10): pp. 25-34.

[6] Catuogno, S., Arena, C., Saggese, S. and Sarto, F. 2016. The Influence of Blockholders, Bondholders and Families on the Venturers' Accounting Behavior. International Journal of Business and Management, 11(8): pp. 31-43.

[7] Cheng, C. (2016). Discussion of 'IFRS non-GAAP earnings disclosures and fair value measurement'. Accounting \& Finance, 56(1): pp. 99-112.

[8] Christensen, B., Glover, S. and Wood, D. 2012. Extreme Estimation Uncertainty in Fair Value Estimates: Implications for Audit Assurance. AUDITING: A Journal of Practice \& Theory, 31(1): pp. 127-146.

[9] Chen, E. and Gavious, I. 2016. Unrealized earnings, dividends and reporting aggressiveness: an examination of firms' behavior in the era of fair value accounting. Accounting \& Finance, 56(1): pp. 217-250.

[10] Cullinan, C. and Zheng, X. 2014. Valuation scepticism, liquidity benefits and closed-end fund premiums/discounts: evidence from fair value disclosures. Accounting \& Finance, 54(3): pp.729-751.

[11] Daske, H., Hail, L., Leuz, C. and Verdi, R. 2008. Mandatory IFRS Reporting Around the World: Early evidence on the economic consequences. Journal of Accounting Research, 46: pp.1085-1142.

[12] Durocher, S. and Gendron, Y. 2014. Epistemic commitment and cognitive disunity toward fair-value accounting. Accounting and Busin. Research, 44(6): pp.630-655.

[13] Funnell, W., Wade, M. and R. Jupe. (2016). Stakeholder perceptions of performance audit credibility. Accounting and Business Research, 46(6): 601-619.

[14] Greuning,H.(2006).Međunarodni standardi finansijskog izveštavanja,Mate, Zagreb.

[15] Guiggiola, G. (2010). IFRS Adoption in the E.U. Accounting Harmonization and Markets Efficiency. Int. Business and Economics Research Journal, 9(12): pp. 99-112.

[16] Williams, C. (2010). Principi menadžmenta, Data Status, Beograd.

[17] Popović, S. 2014. Socio-ekonomski faktori ograničenja razvoja agrara, Monografija, Feljton, Novi Sad.

[18] Popović, S., Majstorović, A. and Grubljesić, Ž. 2015. Valuation of facilities in use and application of international accounting standards. Actual prob.of Economics, 3:379-387.

[19] Popović, S., Novaković, S., Đuranović, D., Mijić, R., Grublješić, Ž., Aničić J. \& Majstorović, A. 2017. Application of international accounting standard-16 in a public company with predominantly agricultural activities. Economic Research-Ekonomska Istraživanja, 30(1): pp.1850-1864. 
[20] Pricope, C. 2016. The role of institutional pressures in developing countries. Implications for IFRS. Theoretical and Applied Economics, 2: pp.27-40.

\title{
ZNAČAJ EVIDENCIJE POLJOPRIVREDNE OPREME U UPOTREBI PREMA FER VREDNOSTI SA STANOVIŠTA UPRAVLJANJA U MALIM I SREDNJIM PREDUZEĆIMA U TRANZICIONOJ DRŽAVI, -PRIMER REPUBLIKE SRBIJE
}

\author{
Jelena Vitomir ${ }^{1}$, Sonja Tomaš-Miskin ${ }^{2}$, Slobodan Popović ${ }^{3}$ \\ ${ }^{1}$ Univerzitet Megatrend, Fakultet za poslovne studije, Bulevar Maršala \\ Tolbuhina 8, 11070 Novi Beograd, Republika Srbija \\ ${ }^{2}$ Ekonomska škola Banja Luka, Kralja Alfonsa XIII/34, 78000 Banja Luka, \\ Bosna i Hercegovina \\ ${ }^{3}$ Javno komunalno preduzeće ,, Gradsko zelenilo “ Temerinski put bb, \\ 21000 Novi Sad, Republika Srbija
}

Sažetak: Ova studija ukazuje na važnost korišćenja realno prikazanih vrednosti poljoprivredne opreme u stvarnim finansijskim izveštajima u srednjim preduzećima. Autori su usvojili suštinu prirode koja se vezuje za procenu poljoprivredne opreme, odnosno, da se u poljoprivrednoj proizvodnji tranzicionih zemalja poljoprivredna oprema koristi i više od pet decenija. To je bila ključna pretpostavka usvojena od autora ovog rada. Osim toga, prikaz realnih finansijskih izveštaja treba da uključi prikaz realne vrednosti poljoprivredne opreme, što suštinski vodi u periodično fer vrednovanje poljoprivredne opreme sa kojom raspolažu nosioci poljoprivredne proizvodnje u tranzicionim državama.

Ključne reči: poljoprivredna oprema, fer vrednovanje, preduzeće.

Prijavljen:

Submitted: 16.11.2020.

Ispravljen:

Revised: 30.01 .2021$.

Prihvaćen:

Accepted: 10.02.2021. 